\title{
Seasonal succession of biomass and microalgal communities in some agricultural drainage at Minia governorate, Egypt
}

\author{
Shereen abdelsalam ${ }^{1}$, Mustafa A. Fawzy ${ }^{2}$, Wafaa A. Hafez ${ }^{3}$ and Adel A. Fathi ${ }^{4}$ \\ ${ }^{1}$ Researcher Assistance, Environmental Department, SWERI, ARC \\ ${ }^{2}$ Biology Department, Faculty of Science, Taif University, 21974, Taif, KSA \\ ${ }^{2}$ Botany \& Microbiology Department, Faculty of Science, Assiut University, Egypt \\ ${ }^{3}$ Senior Researcher, Environmental Department, SWERI, ARC \\ ${ }^{4}$ Department of Botany and Microbiology, Faculty of Sciences, Minia University, \\ Egypt
}

\begin{abstract}
:
The microalgal communities and related physico-chemical properties of some agricultural drainage at Minia, Egypt as well as, the qualitative and quantitative algal composition were seasonally studied. In total, 151 algal species were identified during the study. Bacillariophyceae was the most dominant algal group during the four seasons, followed by Chlorophyceae, Cyanophyceae, Euglenophyceae, Charophyceae and Dinophyceae. Among Bacillariophyceae, Cyclotella striata was the most abundant species, Scenedesmus quadricauda from Chlorophyceae, Oscillatoria limosa from Cyanophyceae, Euglena proxima from Euglenophyceae, Staurastrum sp. from Charophyceae and Peridinium lomnicki from Dinophyceae. The maximum algal biomass was recorded at site 1 in autumn $(827.7 \mu \mathrm{g} / \mathrm{L})$; and the minimum value was recorded at site 4 in winter $(26.7 \mu \mathrm{g} / \mathrm{L})$. Seven diversity indices were obtained that comprise Margalef's Index, Shannon-Wiener Diversity, Pielou's Evenness, Fisher's Index, Simpson Dominance Index, Simpson's Diversity Index and Berger-Parker Index. Water temperature, total alkalinity, chloride and phosphate were the most effective parameters affecting structure of microalgae during the different seasons.
\end{abstract}

Keywords: Microalgae, physico-chemical parameters, diversity indices, algal diversity, drainage. 


\section{Introduction}

The steady increase in population and urban expansion has resulted in a concomitant increase in agricultural and industrial activities, which in turn has reflected an increase in the waste that is discharged into the aquatic environment (Alnagaawy et al., 2018).

The irrigation and drainage canals perform the task of controlling the balance between the water required for irrigation and the drainage of excess water from the cultivated soil. Anthropogenic influences may lead to imbalances in this balance, which leads to special problems in the drainage channels (El-Otify, 2015). Analysis of chemical parameters for water provides a good indication of the chemical quality of aquatic system, but don't present the ecological effects on the ecosystem (Rejagopal et al., 2010). Therefore, the trend is towards adding biological assessment to chemical parameters, as they complement each other to present the extent of the impact of water pollution on biological diversity in the ecosystem in water bodies (Stevenson and Pan, 1999).Phytoplankton provides unique information concerning an ecosystem's conditions and plays a vital role in maintaining balance of the aquatic ecosystem (Field et al., 2007).

The average of ecological condition is attributed to Phytoplankton encountered in the water body. Therefore, they could indicate the quality of the water (Saha et al., 2000).

Algae are found in both clean and polluted water so they can be used, especially microalgae as a sensitive indicator for environmental changes, as well as a biological sensor for the potentially toxic effects of heavy metals (Durrieu $\boldsymbol{e t}$ al., 2011). The use of microalgae as biological indicators are provides information on the surrounding physical and/or chemical environment at a particular site (Bellinger and Sigee, 2010).

The rate of rapid reproduction and sensitivity responses to eutrophication and chemical changes in the water gave algae the advantages that make it very ideal bioindicators in assessing water quality (Larson and Passy, 2012; El-Otify, 2015).The distribution, structure and biomass of microalgae are strongly influenced by chemical factors such as nutrients (Kormas et al., 2006) and variable environmental effectors such like temperature, location, light, $\mathrm{pH}$, water 
level, and seasonal changes (El-Din et al., 2015; Demir et al., 2014). Nutrients are important components in regulating growth of macro and microalgae (Hernández-Carmona et al., 2011). Tóth (2013) stated that phosphorus and nitrogen increase in eutrophic water resulted in increase of planktonic algae. Smith and Manoylov (2013) also reported that the increase in temperature leads to an increase in the diversity of diatoms. El-Otify (2015) observed obvious differences in water quality and phytoplankton abundance as well as its community structure between the irrigation and drainage canals. He noticed that the diversities of species in the irrigation canals are relatively higher than those in the drainage canals. In addition, some Euglenoid and Cyanoprokaryotic phytoplankton found in the drainage canals while absent in the irrigation canals.

Egypt is rich with networks of canals for irrigation and drainage designed for agricultural uses. Agriculture in Egypt is mostly dependent on water from the river Nile. Irrigation canals used to transfer the water from the Nile to the fields however its water may be used for drinking, industrial purposes, navigation and fishing. The main drainage in most parts of upper Egypt discharge their water into the Nile by gravity without any treatment. These drains receive the excess of irrigation water which contains chemicals used for pests or herbs control, domestic wastes effluents from side bank habitations, municipal, rural domestic and industrial wastes (Radwan $\boldsymbol{e t}$ al., 2004). Drainage water usually contains a high salt concentration beside organic load, toxic chemicals, and nutrients and dissolved oxygen depletion (El-Sadek et al., 2003).

The area of middle Egypt such like Minia governorate received less attention to the effects of water pollution especially in drainage canals on algal diversity. Therefore, the aim of the present study is to investigate species diversity, abundance of microalgae as well as biomass variation in different drains at Minia and the accompanied relationships to physicochemical factors that affect the phytoplankton succession. 


\section{Materials and Methods}

\section{Study area and sampling}

Water samples were seasonally collected from five drains at four different pumping stations in south Minia, Egypt (Abu-Jabl, Tuna, Kab-kab, Hassan Pasha and Al-Muhit drain) (Table 1, Fig. 1) during the period from July 2017 to June 2018. Polyethylene bottles were rinsed firstly with sample water and then closed and dipped in the water to about 0.5 meter depth. For collecting the water samples, the bottle was opened inside the water and closed after collecting the sample. Samples were collected as three replicates at each of the five locations however were mixed in the lab to prepare an integrated sample. Samples used for algal survey was preserved immediately in $4 \%$ formalin solution for counting and stored under dark and cool condition. Sedgwick-Rafter cell $1 \mathrm{~cm}^{3}$ was used for counting the microalgae (Ganf, 1974). The biomass of algae was estimated as chlorophyll (mg/L) according to (Metzner et al., 1965) .Species identification was performed according to Kramer and Lange-Bertalot (1991); Lund and Canter-Lund (1995).

\section{Water analysis}

The water temperature was measured in situ by Thermometer. The $\mathrm{pH}$ values were determined using a digital $\mathrm{pH}$ meter $(\mathrm{pH}$ Pen Jenco Electronics, U.S.A).Electrical conductivity was measured in water samples using conductmeter (JENWAY, UK 4510). Total dissolved solids were determined by the method adopted by (Jackson, 1958). Estimation of total alkalinity was performed according to the method described by Mackereth $\boldsymbol{e t}$ al. (1978). Nitrate was determined by sodium salicylate method (Deutsche Einheitsverfahrenzur Wasser- Abwasser -und Schlammuntersuchung, 1960). Dewis and Freitas (1970) method was used for the determination of orthophosphate. Estimation of chlorides was performed according to the method described by (Jackson, 1960). $\mathrm{Na}^{+}$and $\mathrm{K}^{+}$ were determined by the flame photometric technique (Williams and Twine, 1960) using Dr Lange Flame Photometer M 71 D type Nr/LPG. Calcium and magnesium were determined using versene titration method (Schwarzenbach and Biederman, 1948). Dissolved Oxygen (DO) and Biological Oxygen Demand 
(BOD) were determined by Winkler's method (Winkler, 1888). Ammonium $\left(\mathrm{NH}_{4}{ }^{+}\right.$) was estimated by Nesslerization spectrophotometric method (Allen and Coon, 1960). Sulfate-sulfur was determined according to (Sheen et al., 1935) method. Turbidity was measured in water samples using (HACH 2100 Q).All variables were determined in triplicate for each sample.

Table.1. Description of the study sites

\begin{tabular}{|c|c|c|c|c|}
\hline $\begin{array}{c}\begin{array}{l}\text { Site } \\
\text { no. }\end{array} \\
\end{array}$ & Station & Study site & Longitudes & Latitudes \\
\hline 1 & $\begin{array}{l}\text { El-Badraman } \\
\text { pumping } \\
\text { station } \\
\text { (DeirMawas) } \\
\end{array}$ & Abu-Jabl Drain & $30^{\circ} 73^{\prime 2} 29319^{\prime \prime}$ & $27^{\circ} 66^{\prime} 61583^{\prime \prime}$ \\
\hline 2 & $\begin{array}{c}\text { Tuna pumping } \\
\text { station } \\
\text { (Mallawi) }\end{array}$ & Tuna Drain & $30^{\circ} 71 ' 29857 "$ & $27^{\circ} 88^{\prime} 40297^{\prime \prime}$ \\
\hline 3 & $\begin{array}{c}\text { Kab-kab } \\
\text { pumping } \\
\text { station } \\
\text { (Abu Qirqas) }\end{array}$ & Kab-kab Drain & $30^{\circ} 72^{\prime} 88707^{\prime \prime}$ & $27^{\circ} 87^{\prime} 83862^{\prime \prime}$ \\
\hline 4 & $\begin{array}{l}\text { Monshaat El- } \\
\text { Dahab } \\
\text { pumping station } \\
\text { (Minia) }\end{array}$ & Hassan Pasha Drain & $30^{\circ} 71^{\prime} 12838^{\prime \prime}$ & $28^{\circ} 22^{\prime} 39775^{\prime \prime}$ \\
\hline 5 & -- & Al-Muhit Drain & $30^{\circ} 72^{\prime} 71142^{\prime \prime}$ & $28^{\circ} 22^{\prime} 44156^{\prime \prime}$ \\
\hline
\end{tabular}




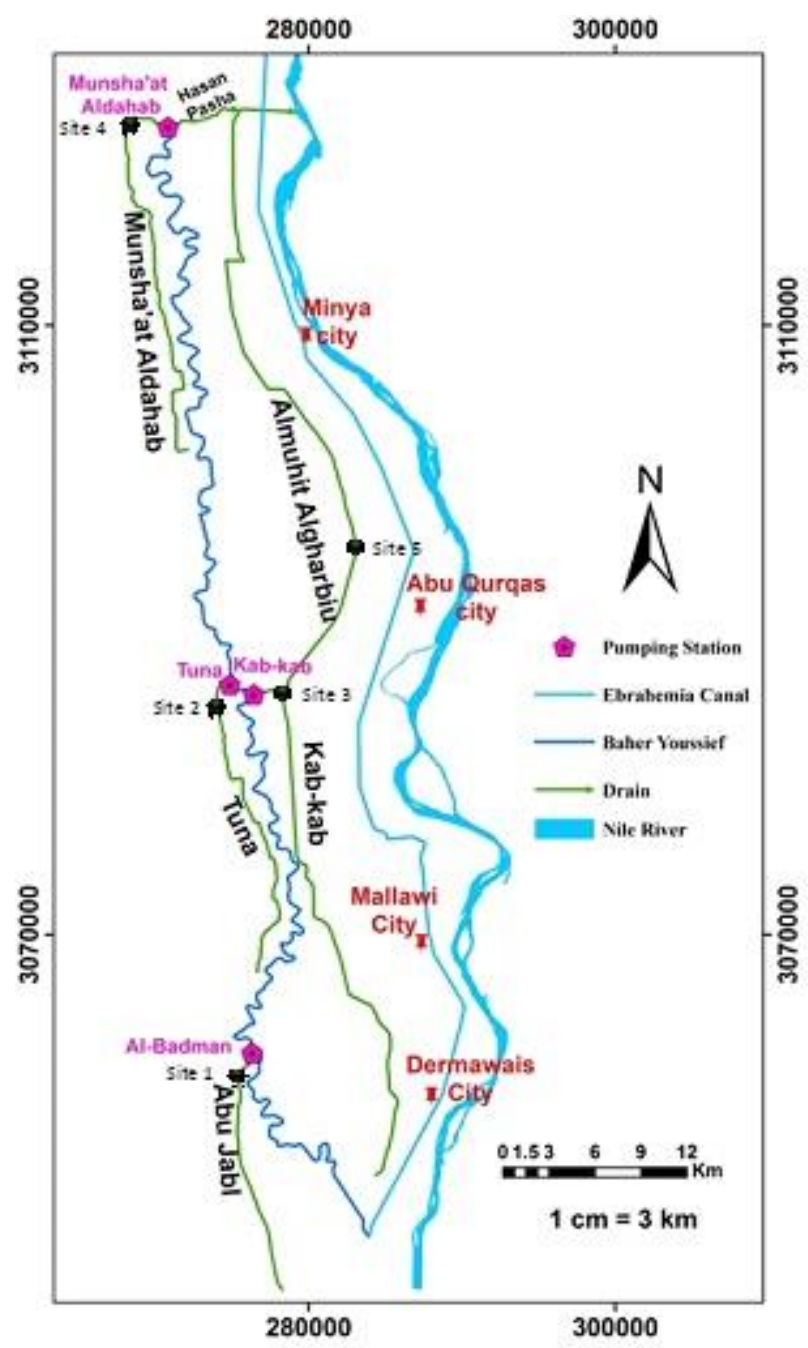

Fig. 1. Map of the study area. 


\section{Community structure analysis}

Margalef's index (d') was used to measure richness of species (Margalef, 1958). Shannon-Wiener diversity $\left(H^{\prime}, \log _{\mathrm{e}}\right.$ based) was calculated depending on Shannon-Wiene (1949). Species evenness was calculated using the Pielou's Evenness Index (J') (Pielou, 1975). A diversity index (Simpson Index) was derived from Simpson (1949).The differences in the structure of algal community between the two studied factors (site and season) were examined by permutational multivariate analysis of variance (PERMANOVA). The analysis of PERMANOVA was carried out by PERMANOVA+ in PRIMER v6 software (Anderson et al., 2008).

A distance-based redundancy analysis (dbRDA) plot allowed the visualization of the relationship between algal species composition and physicochemical variables and highlighted the variability in species composition along the site and season factor using Bray Curtis similarity between algal species. The analysis of dbRDA was carried out by PERMANOVA+ in PRIMER v6 software (Anderson et al., 2008).

\section{Results and Discussion}

\section{Physico-chemical characteristics of the water samples}

Recently, microalgae are used as a sensitive indicator for environmental changes (Durrieu, et al., 2011). Its abundance and composition can be an excellent indicator and sensitivity to the environmental changes (Varadharajan and Soundarapandian, 2014).

The seasonal change of physico-chemical characteristics of the water samples are tabulated in [Table 2]. Seasonal variations in water temperature of the study sites showed wide range of temperature $\left(19^{\circ} \mathrm{C}\right.$ and $\left.34^{\circ} \mathrm{C}\right)$. The data show that change in $\mathrm{pH}$ value was always in the alkaline side. The highest $\mathrm{pH}$ was recorded during autumn (8.6) at site 2 and the lowest $\mathrm{pH}$ was recorded during summer (6.95) at site 5 . 


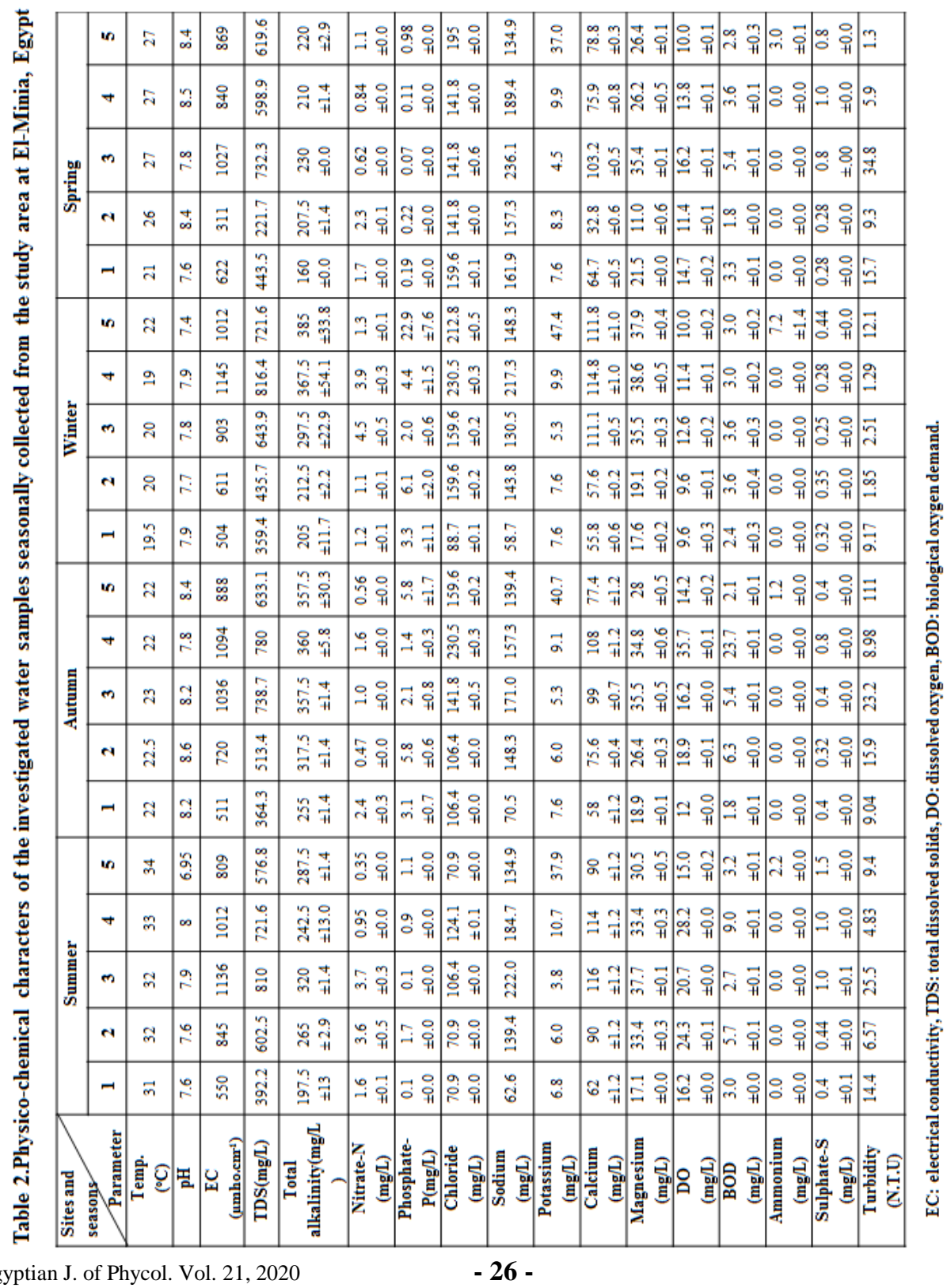


The electrical conductivity and total dissolved solids fluctuated within $311 \mu \mathrm{mho} . \mathrm{cm}^{-1}$ and $221.7 \mathrm{mg} / \mathrm{L}$ during spring at site 2 and $1145 \mu \mathrm{mho.cm}{ }^{-1}$, and $816.3 \mathrm{mg} / \mathrm{L}$ during winter at site 4 , respectively. The biological activities of phytoplankton and epiphytic microalgae especially photosynthesis and respiration has been controlled by the temperature and $\mathrm{pH}$ of aquatic systems, (Sukran et al., 2002). Lashari et al. (2009) stated that, temperature measurements are useful in indicating trends for various chemical, biochemical and biological activities. The $\mathrm{pH}$ value ranged between 6.95 and 8.6 ; this variation is due to the presence or absence of free carbon dioxide and carbonate and planktonic density during various months (Lashari et al., 2009).Toma (2011) found that most aquatic organisms can tolerate to normal $\mathrm{pH}$ range (6.0-9.0), but they are most active when the $\mathrm{pH}$ value is around 7. On the other hand, variations in T.D.S may be attributed to the consumption of salt by algae and other aquatic plants, rate of evaporation as well as the size of the water body, and inflow of water (Lashari $\boldsymbol{e} t$ al., 2009). The increase in E.C. value may be because of presence of salts and dissolved materials at the lake sediments (Toma, 2011). Content of total alkalinity in the water samples ranged between $160 \mathrm{mg} / \mathrm{L}$ at site 1 during spring and 385 $\mathrm{mg} / \mathrm{L}$ at site 5 during winter. This increase may be due to the bacterial decomposition of organic substrates (Abdel-Satar and Elewa, 2001). The turbidity was high (111 N.T.U) at site 5 and low (1.29 N.T.U) at site 4 in autumn and winter, respectively [Table 2]. The turbidity at all sites was within the normal ranges of FAO except at site 3 in summer and spring (25.5 and 34.8 respectively) which was higher than permissible limits of FAO (1985).

Nutrients such as $\mathrm{NO}_{3}, \mathrm{NH}_{4}$ and $\mathrm{PO}_{4}$ play an important role in the productivity of aquatic ecosystems (Graham et al., 2009). In the present study, nitrate-nitrogen showed the maximum content during winter $(4.5 \mathrm{mg} / \mathrm{L})$ at site 3 , whereas the minimum content was recorded in summer $(0.35 \mathrm{mg} / \mathrm{L})$ at site 5 . Phosphate-phosphorus was fluctuated within $0.07 \mathrm{mg} / \mathrm{L}$ at site 3 to $22.9 \mathrm{mg} / \mathrm{L}$ at site 5 during spring and winter, respectively [Table 2]. Abdo (2013) found that elevation in nitrate during cold months might be attributed to low consumption by phytoplankton as well as the oxidation of ammonia by nitrifying bacteria and biological nitrification. The low values of ammonium in some sites probably due to the utilization of $\mathrm{NH}_{4}{ }^{+}$by phytoplankton, sewage and industrial discharges which use ammonium liquor or gas for their production processes (Khalil $\boldsymbol{e t}$ al., 
2014). The high concentrations of total phosphorus and total nitrogen may be due to interaction between the water and sediment which contains dead plants and animal at the bottom of the lake, firm rock deposit and runoff from surface catchments causes release of nutrients to the water column (Tamot and Sharma, 2006). Toma (2011) explained the decline in $\mathrm{PO}_{4}$ values in some sites and seasons may be because of the significant decline in phytoplankton biomass. The data of table [2] show that the content of chloride in the water samples ranged between $70.9 \mathrm{mg} / \mathrm{L}$ at site 1,2 and 5 in summer and $230.5 \mathrm{mg} / \mathrm{L}$ at site 4 during autumn and winter was low in summer and high in autumn and winter. The high concentrations of chloride recorded in this study could be mainly attributed to drain water discharge or to high summer temperature which accelerate evaporations (Al-Sheikh and Fathi, 2010; Fathi et al., 2013)

Monovalent and divalent cations play very important role in the productivity of inland water. The highest content of sodium was recorded in the water samples collected from site $3(236.1 \mathrm{mg} / \mathrm{L})$ in spring, while the lowest content of sodium was recorded in the water sample collected from site $1(58.7 \mathrm{mg} / \mathrm{L})$ in winter. Potassium concentration was the highest $(47.4 \mathrm{mg} / \mathrm{L})$ in winter at site 5 and the lowest value $(3.8 \mathrm{mg} / \mathrm{L})$ was recorded in summer at site 3 . Both sodium and potassium play important role in the productivity of water (Fathi et al., 2013). It is worthy to note that, potassium concentration in the present study higher than the acceptable ranges at all sites according to the FAO for irrigation water. On the other hand, calcium content was seasonally ranged between $116 \mathrm{mg} / \mathrm{L}$ at site 3 and $32.8 \mathrm{mg} / \mathrm{L}$ at site 2 during summer and spring, respectively. The maximum value of magnesium was $38.6 \mathrm{mg} / \mathrm{L}$ at site 4 and the minimum was $11.0 \mathrm{mg} / \mathrm{L}$ that recorded at site 2 in winter and spring, respectively. Elewa (1988) found that the microorganisms play an important role in the exchange of calcium between sediments and submerged water as well as the calcium concentration in water was affected by the adsorption of the calcium ion on the metallic oxides.

Dissolved oxygen is an important parameter for identification of different water masses. The data of this investigation illustrated that the highest value of dissolved oxygen was $35.7 \mathrm{mg} / \mathrm{L}$ at site 4 in autumn and the lowest was zero that recorded at site 5 in all seasons. On the other hand, the biological oxygen demand 
was ranged from $23.7 \mathrm{mg} / \mathrm{L}$ at site 4 in autumn to zero that recorded at site 5 in all seasons. The maximum value of ammonium was $2.2,1.2,7.2$ and $3.0 \mathrm{mg} / \mathrm{L}$ at site 5 in summer, autumn, winter and spring, respectively, and the minimum was zero that recorded at most sites and seasons. Dissolved oxygen (DO) content, plays a vital role in supporting aquatic life and the environment changes. Oxygen depletion often occurs during times of high community respiration, Hence DO have been extensively used as a parameter delineating water quality and to evaluate the degree of freshness of a river (Hassan et al., 2010). El-Gamel and Shafik (1985) stated that depletion in DO might indicate high organic matter and nutrients load. The relatively high concentrations of dissolved oxygen recorded in this study could be mainly attributed to light intensity rather than photosynthetic activity of phytoplankton due to the increased photosynthetic activity of phytoplankton populations (Fathi and Flower, 2005; Fathi et al., 2009). Biological Oxygen Demand (BOD) reflects the degree of organic matter pollution, in the present study BOD was within the normal ranges of FAO $(\leq 6)$ except at site 4 in summers and at site 2, 4 in autumn. As well as, BOD at site 5 (Al-muhit drainage) was away from the acceptable ranges according to FAO, which agree with results obtained by Ali et al. (2014). Sulfate-sulfur concentration ranged between $0.25 \mathrm{mg} / \mathrm{L}$ during the winter at site 3 and $1.5 \mathrm{mg} / \mathrm{L}$ during summer at site 5 [Table 2]. The increase in the concentration of sulfate during the hot period may be attributed to high air and water temperatures followed by high evaporation rate (Toma, 2011).

\section{Community structure}

Phytoplankton communities are sensitive to changes in their environment; therefore its biomass and many species are used as indicators for water quality (Brettum and Andersen, 2005). The biomass and abundance of microalgae varied between different sites and seasons. The present study recorded the maximum algal biomass at site 1 in autumn $(827.7 \mu \mathrm{g} / \mathrm{L})$; on the other hand, the minimum algal biomass was recorded at site 4 in winter (26.7 $\mu \mathrm{g} / \mathrm{L})$ (Fig.2). 


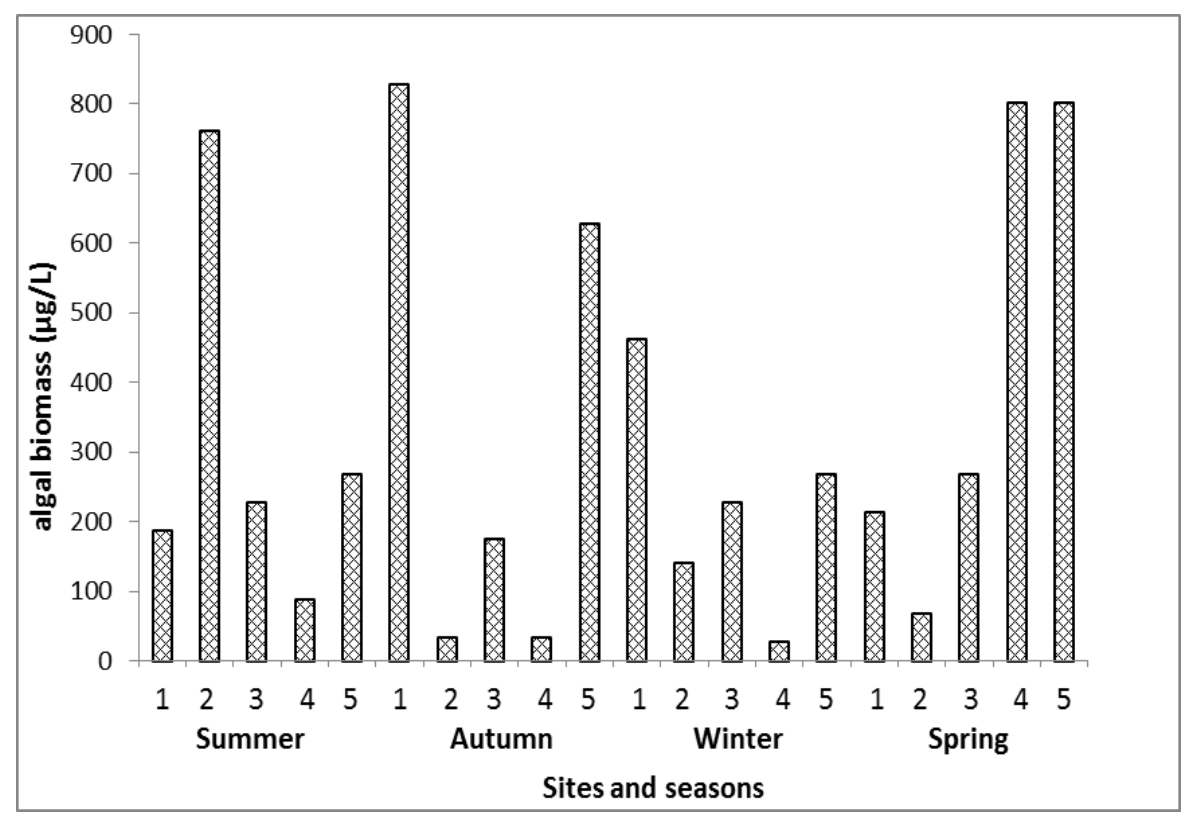

Fig. 2. Changes in algal biomass between the sites and seasons

In total, 151 algal species were identified, of which 78 species (18 genera) belong to Bacillariophyceae, 47species (22genera) belong to Chlorophyceae, 11 species ( 8 genera) belong to Cyanophyceae, 9 species ( 2 genera) belong to Euglenophyceae, 5 species ( 2 genera) belong to Charophyceae and 1 species (1 genus) belong to Dinophyceae (Table 3). Bacillariophyceae was the most dominant algal group during the four seasons (51.6\%), followed by Chlorophyceae (31.1\%), Cyanophyceae (7.3\%), Euglenophyceae (5.9\%), Charophyceae (3.3\%) and Dinophyceae $(0.66 \%)$. The total numbers of members of class Cyanophyceae ranged from $\left(26 \times 10^{3} \mathrm{ind} . \mathrm{L}^{-1}\right)$ in winter at site 4 to $\left(3213 \times 10^{3}\right.$ ind. $\left.\mathrm{L}^{-1}\right)$ in summer at site 5, while the highest numbers of individuals of class Bacillariophyceae $\left(17152 \times 10^{3}\right.$ ind. $\left.\mathrm{L}^{-1}\right)$ was recorded at site 1 in winter and the lowest $\left(2217 \times 10^{3}\right.$ ind. $\left.\mathrm{L}^{-1}\right)$ was found in summer at site 1 (Fig. 3 ). 


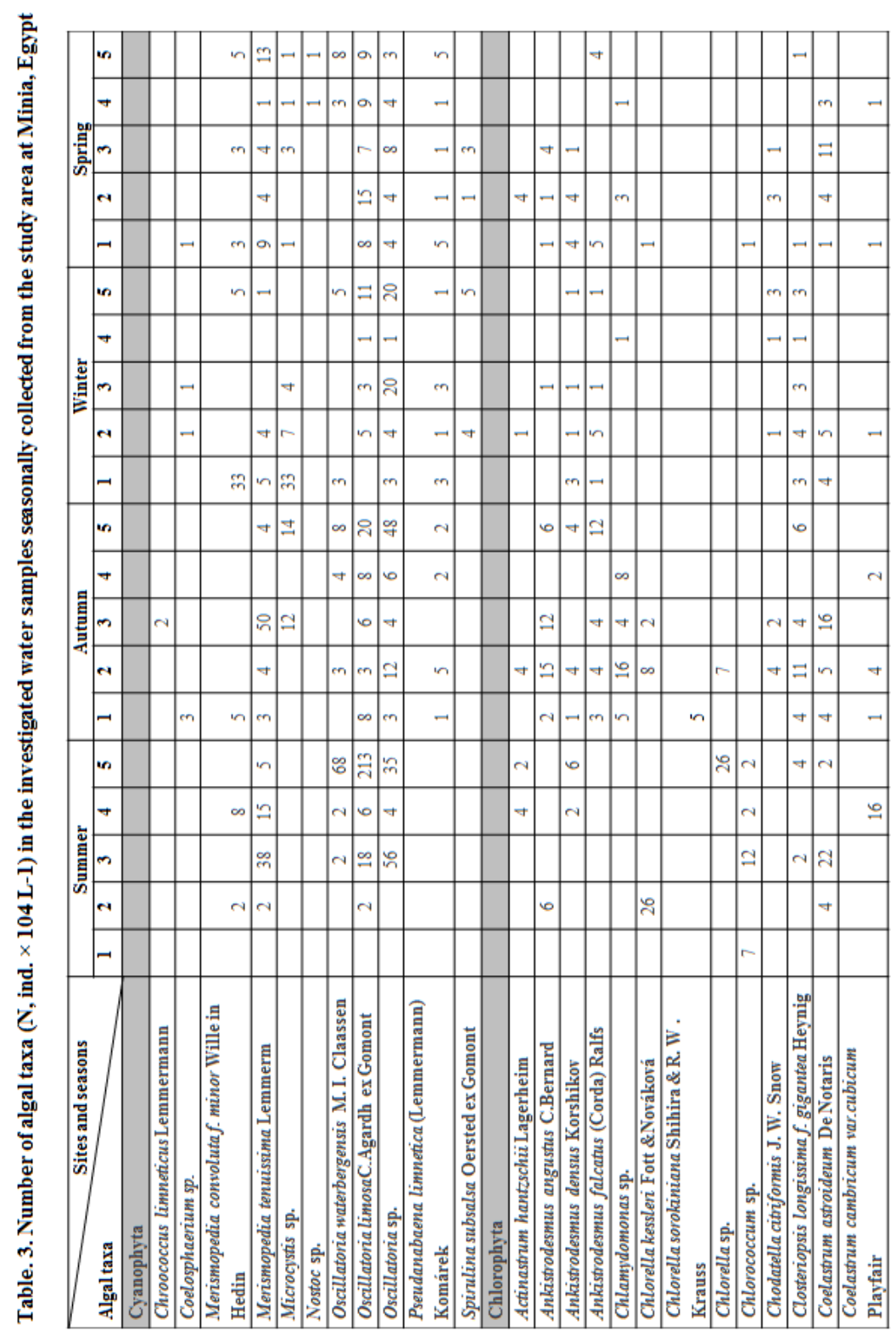

Egyptian J. of Phycol. Vol. 21, 2020 


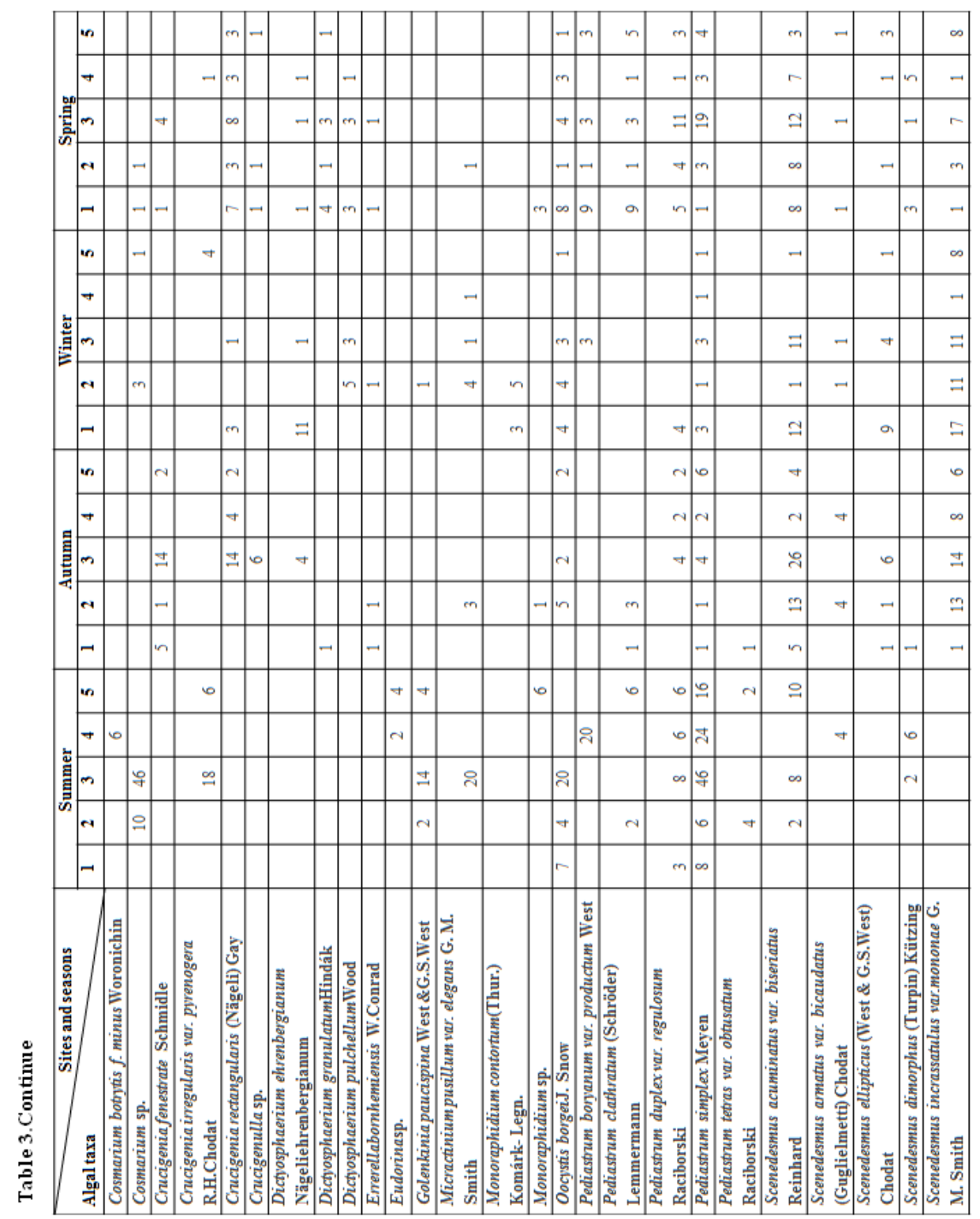




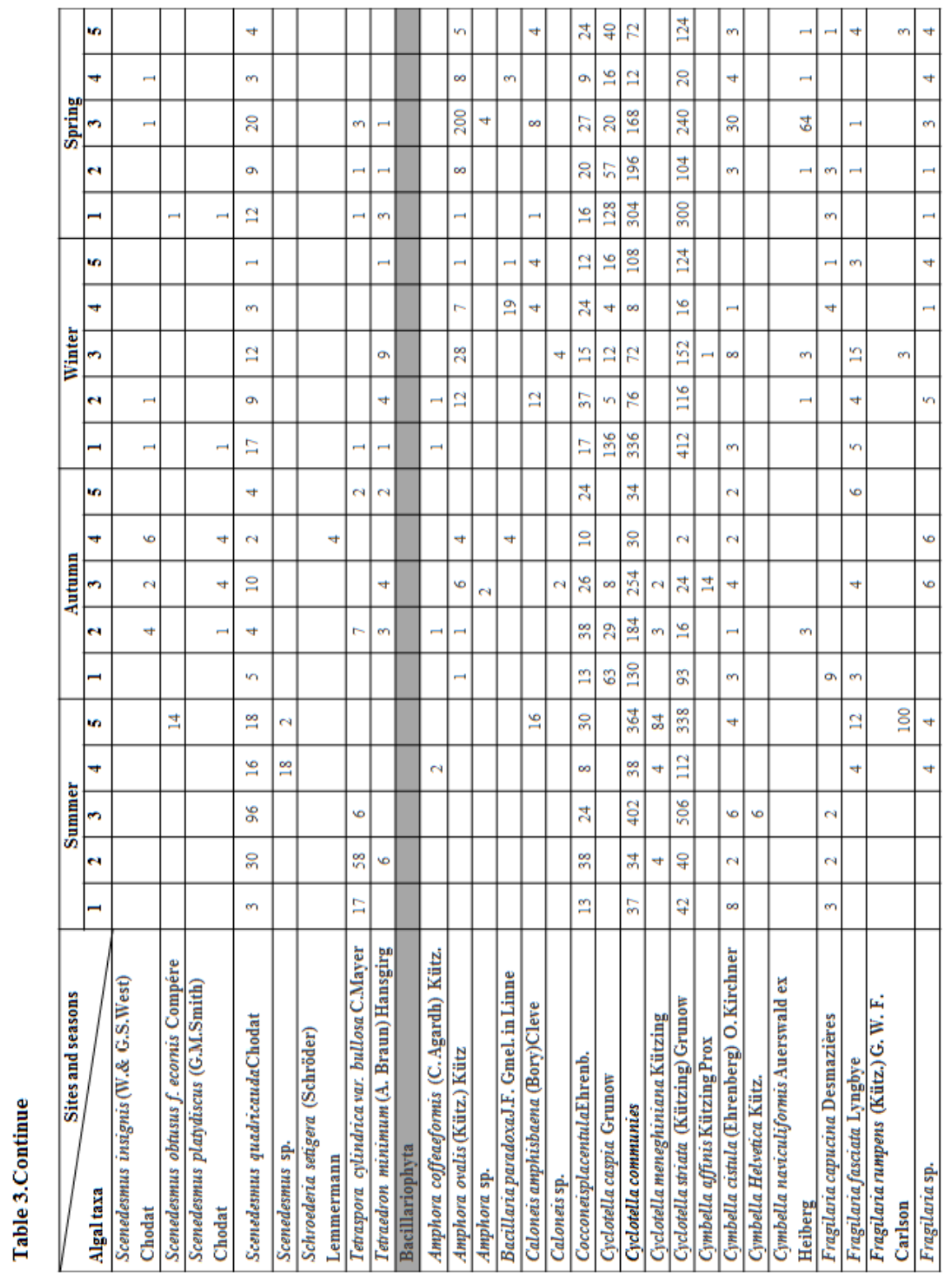




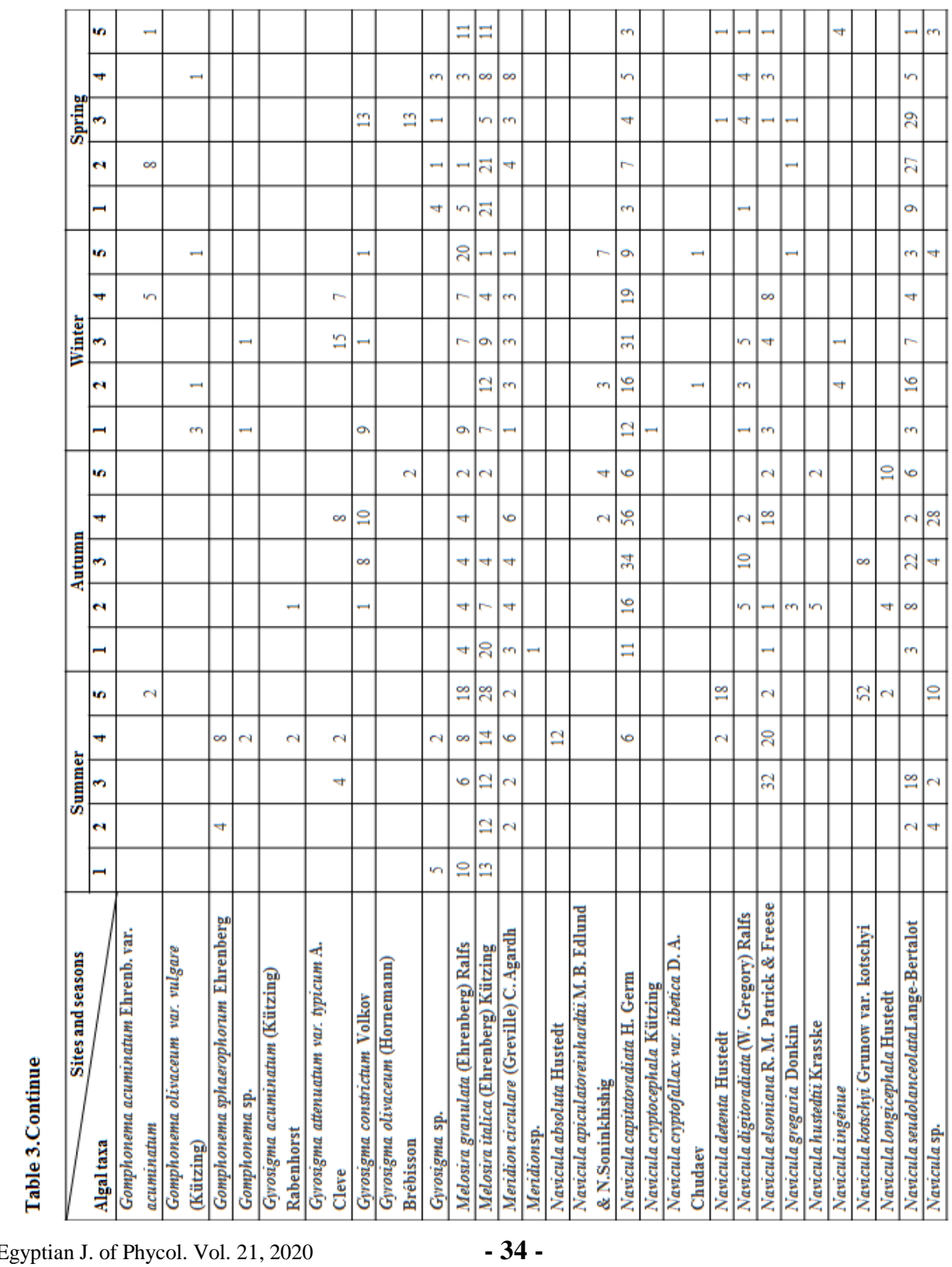




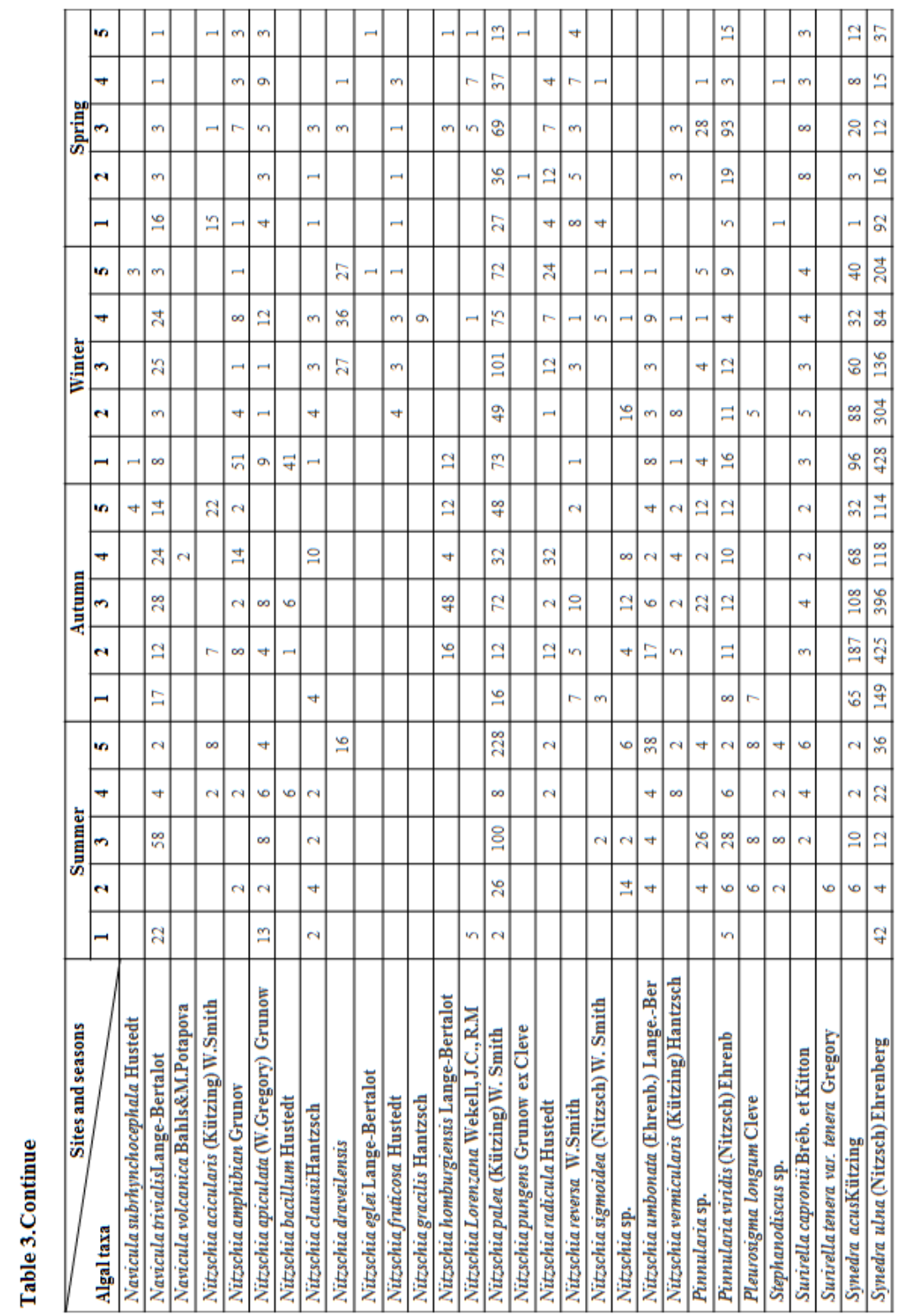




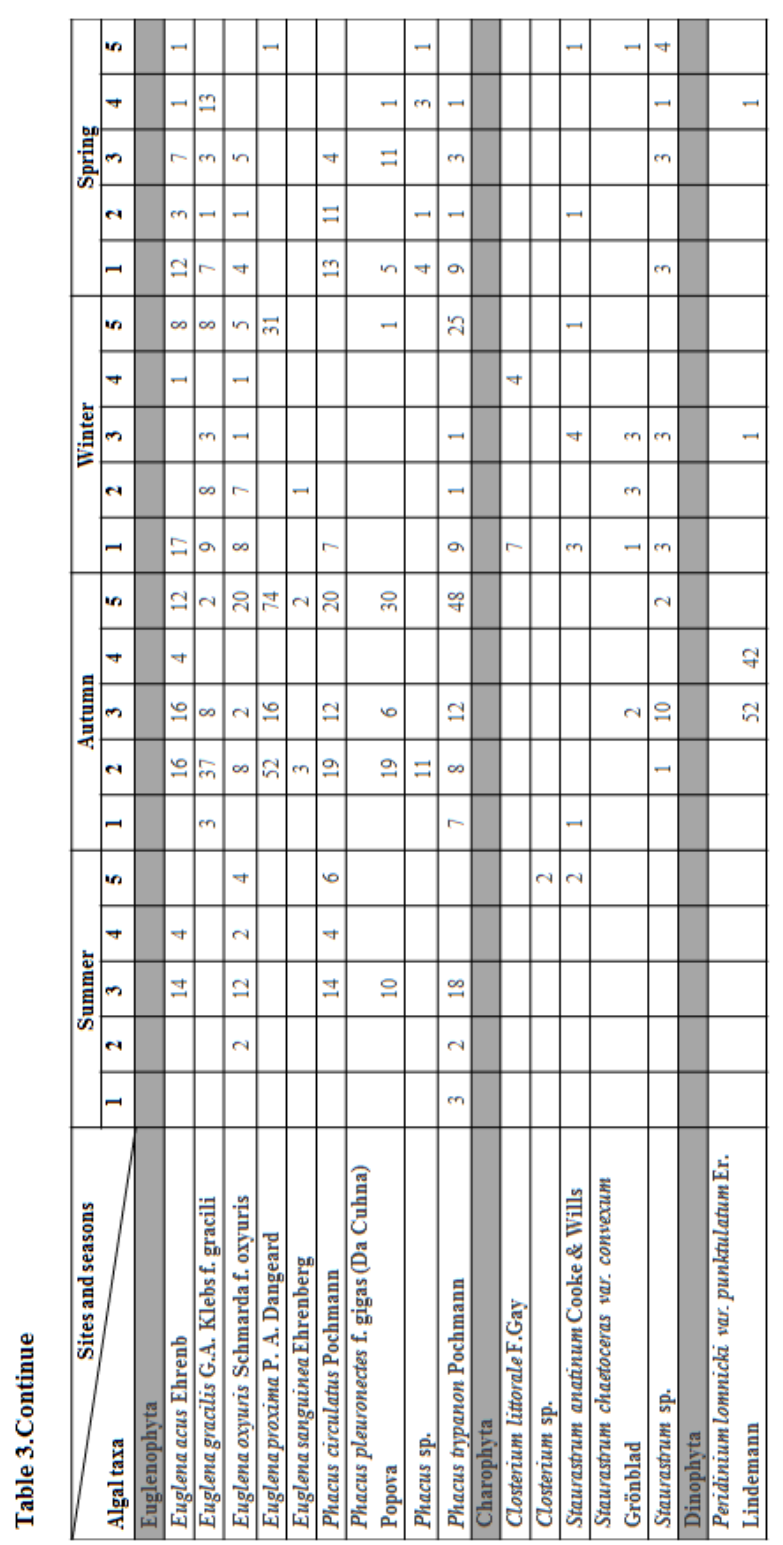

Egyptian J. of Phycol. Vol. 21, 2020

- 36 - 


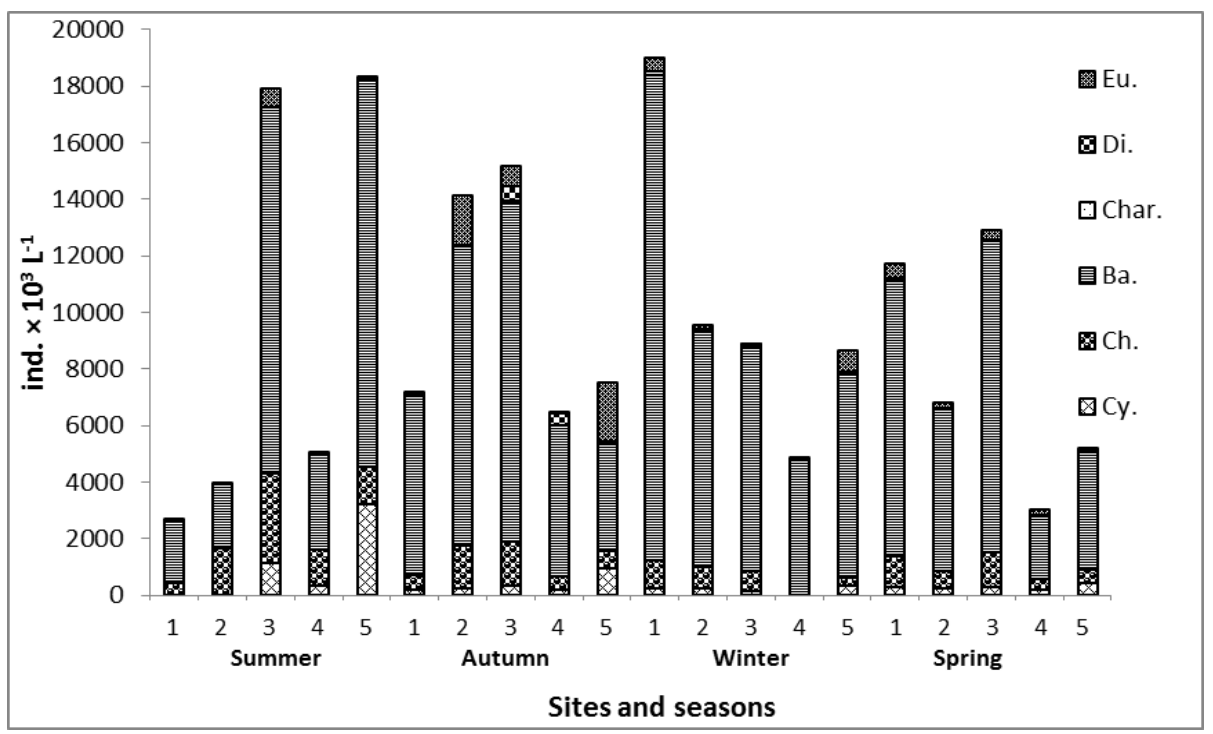

Fig.3. Abundance (ind. $\times 10^{3} \mathrm{~L}^{-1}$ ) of algae found in the study sites

On the other hand, the greatest numbers of individuals of class Chlorophyceae $200 \times 10^{3}$ ind. $\mathrm{L}^{-1}$ ) was recorded in summer at site 3 and the lowest $\left(101 \times 10^{3}\right.$ ind. $\left.\mathrm{L}^{-1}\right)$ was recorded in winter at site 4 . Euglenophyceae individual's number was ranged from $\left(26 \times 10^{3}\right.$ ind. $\left.\mathrm{L}^{-1}\right)$ in winter at site 4 to $\left(2080 \times 10^{3}\right.$ ind. $\left.\mathrm{L}^{-1}\right)$ in autumn at site 5. The numbers of individuals of class Charophyceae $\left(134 \times 10^{3}\right.$ ind. $\left.\mathrm{L}^{-1}\right)$ exceeded in winter at site 1 , whereas fall to $\left(13 \times 10^{3}\right.$ ind. $\left.\mathrm{L}^{-1}\right)$ in autumn at site 1 and 2 , in winter at site 5 and in spring at site 2 and 4 . The numbers of class Dinophyceae members were fluctuated from $\left(13 \times 10^{3}\right.$ ind. $\left.\mathrm{L}^{-1}\right)$ in winter at site 3 and in spring at site 4 to $\left(520 \times 10^{3}\right.$ ind. $\left.\mathrm{L}^{-1}\right)$ in autumn at site 3 (Fig. 3 ). On the other hand, Cyanophyceae was completely absent from site 1 in summer. In addition, Charophyceae was completely absent from site 1,2,3 and 4 in summer, and from site 4 in autumn, as well as, Dinophyceae was completely absent from all sites in summer, from site 1,2 and 5 in autumn, and found only at site 3 in winter and site 4 in spring (Fig. 3). Among Cyanophyceae, Oscillatoria limosa was the most abundant species $\left(213 \times 10^{4}\right.$ ind. $\left.\mathrm{L}^{-1}\right)$ recorded at site 5 in summer (Table 3). Scenedesmus quadricauda from Chlorophyceae was occurred 
in high numbers at site 3 in summer $\left(96 \times 10^{4}\right.$ ind. $\left.L^{-1}\right)$. The highest number of Bacillariophyceae was occurred by Cyclotella striata $\left(506 \times 10^{4}\right.$ ind. $\left.\mathrm{L}^{-1}\right)$ in summer at site 3, Euglena proxima from Euglenophyceae was occurred in high numbers $\left(74 \times 10^{4}\right.$ ind. $\left.\mathrm{L}^{-1}\right)$ in autumn at site 5 , Staurastrum sp. from Charophyceae was occurred in high numbers $\left(10 \times 10^{4}\right.$ ind. $\left.\mathrm{L}^{-1}\right)$ in autumn at site 3 , and Peridinium lomnicki from Dinophyceae was occurred in high numbers $\left(52 \times 10^{4}\right.$ ind. $\left.\mathrm{L}^{-1}\right)$ in autumn at site 3 (Table 3 ).

The diversity indices such as Margalef's Index (d'), Shannon-Wiener diversity (H', loge based), Pielou's evenness (J'), Fisher'sIndex $(\alpha)$, Simpson Dominance index (D), Simpson's Diversity Index (1-D) and Berger-Parker index (d) were studied based on the abundance of algae (Table 4). In the current study, the margalef's index showed that phytoplankton diversity was highest in autumn at site 2 (8.2), while the least diversity was recorded in summer at site 1 (2.7). The maximum value of Pielou's Evenness index was estimated in spring at site 4 (0.9), whereas the minimum was estimated in winter and spring at site $1(0.6)$.In spring, the parametric index of diversity (Fisher's index) was recorded its highest value at site 4(11.9), while it recorded its lowest value in summer at site 1(3.3).The Shannon-Wiener diversity index ranged between 2.7 and3.7 in spring at site 1 and 4 , respectively. On the other hand, Simpson's dominance index was ranged from $(0.04)$ at site 4 to $(0.2)$ at site 1 in spring. It was observed that the highest value of Simpson's index of diversity was recorded at site $4(0.96)$ in spring, while the value was less than $(0.85)$ at site 1 in spring. Finally the highest value of BergerParker index was recorded in winter at site $2(0.32)$ and the lowest was recorded in spring at site 4 (0.07).

The differences in the structure of algal community between the two studied factors (site and season) were examined by a distance-based per mutational multivariate analysis of variance, PERMANOVA. Two wayPERMANOVA on the assemblages of microalgae between the two studied factors revealed that the temporal variation based on the Bray-Curtis similarity was the most important factor that induced the variation in assemblages of algae $(p=0.002)$, followed by the site that able to show the difference between algal species $(\mathrm{p}=0.026$, Table 5). 
Table 4.Community parameters of some agricultural drains at Minia. Number of species (S), total abundance of individuals $\left(\mathrm{N}\right.$, ind. $\left.\times 10^{3} \mathrm{~L}^{-1}\right)$, Margalef's Index (d'), Shannon-Wiener diversity (H', $\log _{\mathrm{e}}$ based), Pielou's evenness ( $\left.\mathrm{J}^{\prime}\right)$, Fisher's Index (a),Simpson Dominance index (D),Simpson's Diversity Index (1-D) and BergerParker index (d).

\begin{tabular}{|c|c|c|c|c|c|c|c|c|c|c|}
\hline Season & Site & $\mathbf{S}$ & $\mathbf{N}$ & $d^{\prime}$ & $\mathbf{J}^{\prime}$ & $\alpha$ & $\begin{array}{c}\mathbf{H}^{\prime} \\
(\log \mathrm{e})\end{array}$ & D & 1-D & d \\
\hline \multirow{5}{*}{ 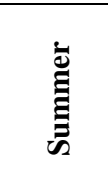 } & S1 & 22 & 2700 & 2.66 & 0.87 & 3.28 & 2.69 & 0.090 & 0.91 & 0.15 \\
\hline & S2 & 42 & 4000 & 4.94 & 0.83 & 6.55 & 3.11 & 0.077 & 0.93 & 0.15 \\
\hline & S3 & 50 & 17936 & 5.00 & 0.69 & 6.28 & 2.70 & 0.142 & 0.86 & 0.28 \\
\hline & S4 & 56 & 5090 & 6.44 & 0.84 & 8.80 & 3.36 & 0.070 & 0.93 & 0.22 \\
\hline & S5 & 60 & 18353 & 6.01 & 0.68 & 7.72 & 2.80 & 0.109 & 0.89 & 0.20 \\
\hline \multirow{5}{*}{ 志 } & S1 & 52 & 7189 & 5.74 & 0.70 & 7.59 & 2.76 & 0.112 & 0.89 & 0.21 \\
\hline & S2 & 79 & 14132 & 8.16 & 0.68 & 11.04 & 2.96 & 0.130 & 0.87 & 0.30 \\
\hline & S3 & 74 & 15200 & 7.58 & 0.72 & 10.12 & 3.10 & 0.108 & 0.89 & 0.26 \\
\hline & S4 & 51 & 6480 & 5.70 & 0.81 & 7.55 & 3.19 & 0.070 & 0.93 & 0.18 \\
\hline & S5 & 57 & 7520 & 6.27 & 0.82 & 8.38 & 3.33 & 0.057 & 0.94 & 0.15 \\
\hline \multirow{5}{*}{ : } & S1 & 67 & 19028 & 6.70 & 0.61 & 8.71 & 2.57 & 0.140 & 0.86 & 0.22 \\
\hline & $\mathrm{S} 2$ & 68 & 9578 & 7.31 & 0.67 & 9.89 & 2.83 & 0.136 & 0.86 & 0.32 \\
\hline & S3 & 67 & 8914 & 7.26 & 0.74 & 9.84 & 3.10 & 0.083 & 0.92 & 0.17 \\
\hline & S4 & 51 & 4860 & 5.89 & 0.79 & 7.95 & 3.12 & 0.076 & 0.92 & 0.17 \\
\hline & S5 & 65 & 8671 & 7.06 & 0.69 & 9.54 & 2.89 & 0.106 & 0.89 & 0.24 \\
\hline \multirow{5}{*}{ ڤ્م } & S1 & 75 & 11748 & 7.90 & 0.61 & 10.71 & 2.65 & 0.153 & 0.85 & 0.26 \\
\hline & S2 & 65 & 6822 & 7.25 & 0.69 & 9.95 & 2.90 & 0.123 & 0.88 & 0.29 \\
\hline & S3 & 78 & 12903 & 8.14 & 0.71 & 11.04 & 3.08 & 0.090 & 0.91 & 0.19 \\
\hline & $\mathrm{S} 4$ & 66 & 3049 & 8.10 & 0.88 & 11.89 & 3.71 & 0.038 & 0.96 & 0.07 \\
\hline & S5 & 65 & 5221 & 7.48 & 0.75 & 10.46 & 3.13 & 0.094 & 0.91 & 0.24 \\
\hline
\end{tabular}

Table 5. Results of two-way PERMANOVA tests (with the site [Si] as a fixed factor and season (Se) as a random factor).

\begin{tabular}{|c|c|c|c|c|c|c|}
\hline $\begin{array}{c}\text { Source of } \\
\text { variation }\end{array}$ & df & SS & MS & Pseudo-F & P(perm) & $\begin{array}{c}\text { Unique } \\
\text { perms }\end{array}$ \\
\hline Si & 4 & 9629.5 & 2407.4 & 1.7082 & 0.026 & 998 \\
\hline Se & 3 & 11741 & 3913.8 & 2.777 & 0.002 & 999 \\
\hline Res & 12 & 16912 & 1409.3 & & & \\
\hline Total & 19 & 38283 & & & & \\
\hline
\end{tabular}

df, degrees of freedom; SS, sum of squares; MS, mean squares; Res, residuals. 
The dbRDA plots allowed the visualization of the relationship between algal species composition and physico-chemical variables and highlighted the variability in species composition along the site and season factor using Bray Curtis similarity between algal species (Fig. 4). Temporal and spatial variations in the composition of microalgae were correlated with physico-chemical properties of water. Water temperature, total alkalinity, chloride and phosphate were the highest abiotic variables correlated with variation in algal composition, for example, water temperature showed higher positive correlation to the algal community collected from site 1, 2, 4 and 5 in spring and summer seasons, while alkalinity, chloride and phosphate showed higher positive correlation to the algal community collected from site 2, 3, 4 and 5 in autumn and winter seasons (Fig. 4).

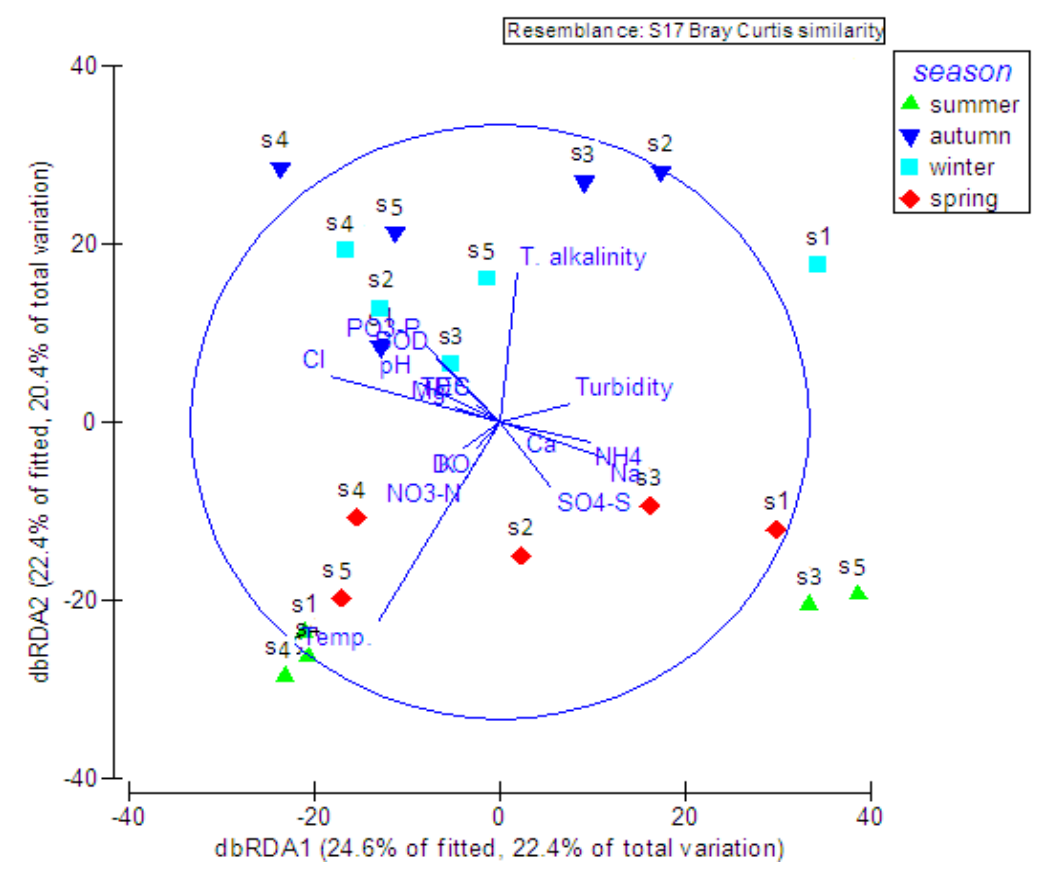

Fig. 4. Distance-based redundancy analysis (dbRDA). Relationships between the ordination of the sites and season based on microalgal species composition and environmental factors 
Phytoplankton communities are sensitive to changes in their environment; therefore its biomass and many species are used as indicators for water quality (Brettum and Andersen, 2005). The biomass of phytoplankton may depend on biotic and abiotic conditions of the water body (Toporowska et al., 2008). Song et al. (2017) found that algal biomass was enhanced when the level of nitrogen and phosphorus concentration was elevated in the water body. Laugaste and Reunanen (2005) also found that maximum algal biomass was estimated in autumn. Bacillariophyceae was the most dominant algal group in this study during the four seasons, this may be attributed to the highly competitive advantage on the nutrients over the other classes of algae (Muller, 1996), followed by Chlorophyceae, Cyanophyceae, Euglenophyceae, Charophyceae and Dinophyceae. These results were in agreement with Elewa et al. (2009) and Shehata et al.(2008), who pointed out that most of the recorded phytoplankton of Rosetta Branch, dominated mainly by Bacillariophyta and Chlorophyta, while Pyrrophyta and Euglenophyta were persisted as rare forms. Shehata et al. (1996), Salman et al. (2013) and Fawzy (2016) found also the same results. Bacillariophceae are characterized as tolerant to mesosaprobic to polysaprobic conditions, and to high nitrogen content (García et al., 2012) and often used as bioindicators for the ecological status of aquatic environments (Pouličkowá $\boldsymbol{e t ~ a l . , ~}$ 2004).Cyanophyta often dominate the fresh-water phytoplankton community in surface waters, particularly in eutrophic system (Codd et al., 1989).

The highest algal species diversity was observed in winter and autumn; this is may be due to the highest values of some nutrients such as nitrate, phosphate and sulphate recorded in the winter and autumn (Adam et al., 2017). Sabae and Abdel-Satar (2001) explained the relation between nitrate and total algal counts that, the minimum level of nitrate corresponded by maximum values of algal counts whereas, the decrease in nitrate concentrations in spring and summer months was might be due to the uptake of nitrate by natural phytoplankton and its reduction by denitrifying bacteria. Variation in the total number of microalgal species may be due to several factors such as chemical and physical factors (Dere et al., 2002) or the water quality and variation of nutrients (Kupferberg, 2003).Alterations in light intensity may also change the species richness, biomass and abundances of algae (Takashi et al., 2004). Aboellil and Aboellil (2012) explained that density and distribution of epiphytic microalgae in 
Nile River were dependent on the variation of $\mathrm{pH}$, nutrient transparency of water and temperature. In the current study, Oscillatoria limosa (Cyanophyceae) was the most abundant species recorded at site 5 in summer. Gadag et al. (2005) stated that occurrence of Oscillatoria was indicating pollutants of biological origin. Albay and Akçaalan (2003) reported that Cyanophyta have a wide range of tolerance to physical disturbance including the fluctuation of water level and large amounts of suspended solids. On the other hand, Scenedesmus quadricauda from Chlorophyceae was occurred in high numbers at site 3 in summer which also indicate pollutants of biological origin according to Gadag et al. (2005). Euglena proxima from Euglenophyceae was occurred in high numbers in autumn at site 5, it is act as an indicator of water quality with some species being indicators of organic pollution (Costica, 2009).Dominance of Chlorella, Scenedesmus, Pediastrum, Oscillatoria, Melosira, Navicula, Nitzschia, Gomphonema, Euglena, etc. were considered to be indicators of organic pollution (Kshirsagar et al., 2012).

The highest number of Bacillariophyceae was occurred by Cyclotella striatain summer at site 3. Ariyadej et al. (2004) found that Cyclotella meneghiniana and Melosira varians might be used as bioindicators of the oligomesotrophic status in Banglang Reservoir, Yala Province.

In the present study, the greatest value of the Simpsons diversity index was observed in spring at site 4 and the least diversity was observed in spring that present at site (1) Shannon and Weiner diversity index (1949) represents entropy. Wilhm and Dorris (1968) after studying diversity in the range of polluted and unpolluted ecosystems concluded that the values of Shannon-Wiener diversity index greater than 3indicated clean water, values in the range of 1-3 considered moderate pollution and the values less than 1 described heavily polluted conditions. Applying this index in the present study, it was found that the highest value of Shannon-Wiener diversity index was observed in spring at site 4 . Pielou's Evenness index (1975) indicated that the species evenness is diversity index, a measure of diversity that determines how equal the community is numerically. The higher value is recorded in spring at site 4. Margalef's index has no limit value and it displays a variation that depends on the species number. Therefore, it is used for the comparison of sites (Kocatas and Bilecik, 1992) and takes into account only one component of diversity (species richness) reflecting 
the sensitivity to sample size. Values of Margalef's diversity index in this study were between 8.16 and 2.66 in autumn and summer at site 2 and 1, respectively. Fisher's index (1943) is a mathematical calculation evaluates the diversity within a community. It relates a number of individuals and number of species. The data of Fisher's index in autumn that present at site 2 and in spring at site 3 are very high and indicate an abundance of species. The Berger-Parker index (1970) is the number of individuals in the dominant taxon divided by the number of individuals. It is affected by the evenness of the indices (Shannon and Weiner, 1949).According to this study, site 4 in spring has the least Berger-Parker index and site 2 in winter has the highest index.

PERMANOVA analysis revealed that, temporal variation was the most important factor, beside the sites that induced variation in algal assemblage. Temporal variation in algal composition was correlated with physico-chemical properties of water.

The analysis of dbRDA highlighted the importance of water temperature, total alkalinity, chloride and phosphate that were more evident in changing the structure of microalgae during the different seasons. This environmental disturbance induced variation in the diversity and abundance of microalgae as well as chemical constituents (Abou-Aisha et al., 1997). Sundbäck and Snoeijs (1991) reported that the nutrients addition led to certain changes in species dominance of the diatoms, but changes were clearer at the macroscopic level (an increase in the filamentous green algae) than in the microflora. Thus, the seasonal investigation of microalgae showed, the variations of nutrient content affected the distribution, abundance and diversity of the microalgal communities, which, in turn, would reflect the physico-chemical analysis of water.

\section{Conclusion}

The study concluded that there was a seasonal variation of algae composition that mostly depending on the physico-chemical parameters. Temperature, total alkalinity, chloride and phosphate were the most effective parameters that affect the microalgal structure. Cyclotella striata, Scenedesmus quadricauda, Oscillatoria limosa, Euglena proxima, Staurastrum sp. and Peridinium lomnicki were the most dominant species in the freshwater drainage. 


\section{References}

Abdel-Satar, A.M. and Elewa, A. (2001). Water quality and environmental assessments of the River Nile at Rosette branch. Proceedings of the 2nd Conference and Exhibition for Life and Environment, Apr. 3-5, Alexandria, Egypt, pp: 136-

Abdo, M. H. (2013). Physico-chemical studies on the pollutants effect in the aquatic environment of Rosetta branch River Nile, Egypt. Life Science Journal, 10 (4): 493-501.

Aboellil, A. and Aboellil, A.H. (2012). Colonization Abilities of Microflora to Attach Aquatic Plants. Global Journal of Science Frontier Research, Biological Sciences, 12(4):21-27.

Abou-Aisha, K. M., Shabana, E. F., El-Abyad, M. S., Kobbia, I. A. and Schanz, F. (1997). Seasonal changes in Cystoseira myrica and phosphorus input at two sites of the Red Sea Egyptian Coast. Water, Air, and Soil Pollution, 93(1-4): 199-211.

Adam, A. S., Hifney, A., Fawzy, M. and Al-badaani, A. (2017). Seasonal biodiversity and ecological studies on the epiphytic microalgae communities in polluted and unpolluted aquatic ecosystem at Assiut, Egypt. European Journal of Ecology, 3 (2), 92-106.

Albay, M. and Akçaalan, R. (2003). Comparative study of periphyton colonization on common reed (Phragmitesaustralis) and artificial substrate in a shallow lake, Manyas, Turkey. Hydrobiologia, 506(1-3): 531-540.

Ali, E. M., Dessouki, S. A., Soliman A. R. and Shenawy A. S. (2014). Characterization of Chemical Water Quality in the Nile River, Egypt, International Journal of pure and applied bioscience, 2 (3): 35-53.

Allen, S. I. and Coon, H. O. (1960). observations on the effect of exercise on blood ammonia concentration in man. Yale Journal of Biology and Medicine, 33: 133-144. 
Alnagaawy, A. M., Sherif, M. H., Mohammed, G. A. and Shehata, A. S. (2018). Impact of industrial pollutants on some water quality parameters of Edku, Mariout lakes and the Nile River. International Journal of EnvironmentalResearch and Public Health, 7(1): 1-15.

Al-Sheikh, H. and Fathi, A. A. (2010). Ecological Studies on Al-Asfar Lake, AlHassa, Saudi Arabia, with Special References to the Sediment, Research Journal of environmental science, 4(1): 13-22.

Ariyadej, C., Tansaku, R., Tansakul, P. and Angsupanich, S. (2004). Phytoplankton diversity and its relationships to the physico-chemical environment in the Banglng Reservoir, Yala. Songklanakarin. Journal of Science and Technology, 26(5): 595-607.

Anderson, M. J., Gorley, R. N. and Clarke, K. R. (2008). PERMANOVA+ for PRIMER: guide to software and statistical methods.

Bellinger, G. E. and Sigee, D. C. (2010). Freshwater Algae: Identification and Use as Bioindicators. Hoboken, NJ: John Wiley \& Sons, Ltd.

Berger, W. H. and Parker, F. L. (1970). Diversity of planktonic foraminifer in deep sea sediments. Science, 168: 1345-1347.

Brettum, P. and Andersen, T. (2005). The use of phytoplankton as indicators of water quality. NIVA-report SNO. 4818-2004: 197 pp.

Codd, G. A., Bell, S. G. and Brooks, W. P. (1989). Cyanobacterial toxins in water. Water Science Technology Journal, 21: 1-13.

Costica, M. (2009). Contribution to knowledge of Euglenophyta in the Bahlui river basin. Analele Stiintifice ale Universitatii" Al. I. Cuza" din Iasi, 55: 163-169.

Demir, A. N., Fakioğlu, Ö. and Dural, B. (2014). Phytoplankton functional groups provide a quality assessment method by the $\mathrm{Q}$ assemblage index in Lake Mogan (Turkey). Turkish Journal of Botany, 38: 169-179.

Dere, Ş., Karacaoğlu, D. and Dalkiran, N. (2002). A study on the epiphytic algae of the Nilüfer Stream (Bursa). Turkish Journal of Botany, 26(4): 219-234. 
Deutsche EinhiestsverfahrenzurWasser, Abivasser und Schlamm. Untersuchung. (1960). Verlag Chemic, Cambh, D9-D10 Weinhern, Bergstr, W. Germany. [c.f. Abd El-Khalek, A.B. (1990). Microbiological studies on sausage. M. Sc. Thesis, Fac. of Agric., Ain Shams Univ., Egypt].

Dewis, J. and Freitas, F. (1970). Physical and chemical methods of soil and water analysis, (10) pp. 275.

Durrieu, C., Guedri, H., Fremion, F. and Volatier, L. (2011). Unicellular algaeused as biosensors for chemical detection in the Mediterranean lagoon andcoastal waters. Research Journal of Microbiology, 162: 908914.

El-Din, S. N., Shaltout, N. A., Nassar, M. Z. and Soliman, A. (2015). Ecological studies of epiphytic microalgae and epiphytic zooplankton on seaweeds of the Eastern Harbor, Alexandria, Egypt. American Journal of Environmental Sciences, 11(6): 450.

Elewa, A. A., Shehata, M. B., Mohamed, L. F., Badr, M. H. and Abdel Aziz, G. S. (2009). Water Quality Characteristics of the River Nile at Delta Barrage with Special Reference to Rosetta Branch. Global Journal of Environmental Research, 3(1): 1-6.

Elewa, A. S. (1988). The influence of oxidation-reduction potential on the water environment of Aswan high dam reservoir. International Journal of Water Resources Development, 4(3): 184-190.

El-Gamal, A. and Shafik, Y. (1985). Monitoring of pollutants discharging to the River Nile and their effect on river water quality. Water Quality Bulletin, WHO, Environmental Canada, 10(3): 111-115 and page 161.

El-Otify, A. M. (2015). Water Quality Assessment of Irrigation and Drainage Systems on the basis of Phytoplankton analysis. The Egyptian Society for Environmental Sciences, 32: 191-202.

El-Sadek, A., Oorts, K., Sammels, L., Timmerman, A., Radwan, M. and Feyen, J. (2003). Comparative study of two nitrogen models. Irrigation and Drainage Engineering, 1 (129): 44-52.

Fathi, A. A. and Flower, R.J. (2005). Water Quality and phytoplankton communities in Lake Qarun (Egypt), Aquatic Science, 67 (4):350-362. 
Fathi, A.A, Abdelzaher, H.M., Flower, R., Ramdani, M. and Kraiem, M. (2001). Phytoplankton communities in North African wetland lakes: The CASSARINA Project. Aquatic Ecology, 35: 303-318.

Fathi, A.A., Al-Fredan, M.A. and Youssef, A.M. (2009). Water Quality and Phytoplankton Communities in Lake Al-Asfar, Al-Hassa, Saudi Arabia., Research Journal of Environmental Science, 3(5):505-513.

Fathi, A.A., Azooz, M. M. and Al-Fredan, M.A. (2013). Hydrobiological investigation of Al-Asfar Lake, Al-Hassa, Saudi Arabia. El-Minia Science Bulletin, 24 (1):21-36.

Fawzy, M. A. (2016). Spatial distribution of epiphytic algae growing on the aquatic macrophytes phragmites australis and echinochloa stagnina at Assiut-Egypt. Minia Science Bulletin, Botany section, 27(2): 1-26.

Field, C. B., Behrenfeld, M. J., Randerson, J. T. and Falkowski, P. (2007). Primary production of the biosphere: integrating terrestrial and oceanic components. Science, 281(5374): 237-240.

Fisher, R. A., Corbert, A. S. and Williams, C. B. (1943). The relation between the numbers of species and the number of individuals in a randomsample of an animal population. Journal of Animal Ecology. 12: 42-58.

Food and Agriculture Organization of the United Nations Rome (FAO) (1985). Mid-decade review of food and agriculture. 19.

Gadag, S. S., Kodashettar, M. S., Birasal, N. R. and Sambrani, M. I. (2005). A checklist of the microphytes and macrophytes in and around Heggerilake (Haveri district). Proc. State level UGC sponsored seminar on biodiversity and its conservation held at KLE society's Gudleppa Hallikeri College, Haveri, p.91.

Ganf, G. G. (1974). Diurnal mixing and the vertical distribution of phytoplankton in a shallow equatorial lake (Lake George, Uganda). The Journal of Ecology, 611-629.

García, V. S., Cantoral-Uriza, E. A., Alcántara, I. I. and Maidana, N. I. (2012). Epilithic diatoms (Bacillariophyceae) as indicators of water quality in the Upper Lerma River, Mexico. Hidrobiologica, 22(1): 16-27. 
Gorelick, R. (2006). Combining richness and abundance into a single diversity index using matrix analogues of Shannon's and Simpson's indices. Ecography, 29: 525-530.

Graham, J. E., Graham, J. M. and Wilcox, L. (2009). Algae, $2^{\text {nd }}$ Edn. Benjamin. Cummings. San Francisco. pp. 698.

Hassan, K. Y., Kutama, A. S. and Ibrahim, Y. (2010). Algal diversity in relation to physico-chemical parameters of three ponds in Kano metropolis, Nigeria. Bioscience Research Communications, 22 (6): 321328.

Hernández-Carmona, G., Riosmena-Rodríguez, R., Serviere-Zaragoza, E. and Ponce-Díaz, G. (2011). Effect of nutrient availability on understory algae during El Niño Southern Oscillation (ENSO) conditions in Central Pacific Baja California. Journal of Applied Phycology, 23: 635-642.

Jackson, M. L. (1958). Soil chemical Analysis. Constable. Ltd. Co., London.498.

Jackson, M. L. (1960). Soil chemical analysis. Constable and Co., London, pp, 261-262.

Khalil, M. A., Beltagy, E. A., Elshouny, W. A., Abo El-Naga, E. H., Elshenawy, M. A. and Kelany, M. S. (2014). Seasonal Bacteriological and Physico-Chemical Analysis of Lake Timsah, Ismailia, Egypt. Life Science Journal, 15: 9-17.

Kocatas, A. and Bilecik, N. (1992). Aegean Sea and Its Living Resources. T. C. Tarimve Köyisleri Bakanligi. Su ÜrünleriArastirma Enstitüsü Müdürlügü. Bodrum.Seri A. 7: 88 pp. (in Turkish).

Kormas, K. A., Nicolaidou, A. and Reizopoulou, S. (2006). Temporal variation of nutrients, chlorophyll a and particulate matter in three coastal lagoons of Amvrakikos gulf Ionian Sea, Greece. Marine Ecology, 22: 201-213.

Kramer, K. and Lange-Bertalot, H. (1991). Süßwasserflora von Mitteleuropa, Band 2/4, Teil 4: Achanataceae, KritischeErgänzungenzuNavicula (Lineolatae) und Gomphonema GesmatliteraturzeichnisTeil 1-4. Gustav Fischer Verlag, Stuttgart Jena, 437. 
Kshirsagar, A. D., Ahire, M. L. and Gunale, V. R. (2012). Phytoplankton diversity related to Pollution from Mula River at Pune City. Terrestrial \& Aquatic environmental Toxicology, 6(2): 136-142.

Kupferberg, S. (2003). Facilitation of periphyton production by tadpole grazing: functional differences between species. Freshwater Biology, 37: 427-439.

Larson, C. A. and Passy, S. I. (2012). Taxonomic and functional composition of the algal benthos exhibits similar successional trends in response to nutrient supply and current velocity. FEMS Microbiology Ecology,80(2): 352-362.

Lashari, K. H., Korai, A. L., Sahato, G. A. and Kazi, T. G. (2009). Limnological studies of Keenjhar lake, district, Thatta, Sindh, Pakistan. Pakistan Journal of Analytical and Environmental Chemistry, 10(1-2): 39-47.

Laugaste, L. and Reunanen, M. (2005). The composition and density of epiphyton on some macrophyte species in the partly meromictic Lake Vervi. Hydrobiologia, 547: 137-150.

Lund, J. W. G. and Canter-Lund, H. (1995). Freshwater algae: their microscopic world explored. BiopressItd. The Ochard Clanage Road Bristol BS3 2JX England, pp. 306.

Mackereth, F. J. H., Heron, J. and Talling, J. F. (1978). Water analysis: some revised methods for limnologists. Freshwater Biological Association, London. 121p. (Scientific Publications, 36).

Margalef, R. (1958). Temporal succession and spatial heterogeneity in phytoplankton. In: Perspectives in Marine biology. Buzzati-Traverso (Ed.). The University of California Press, Berkeley, 323-347.

Melo, A. S. (2008). O queganhamos 'confundindo' riqueza de espécies e equabilidadeem um índice de diversidade. Biota Neotropica, 8: 21-27.

Metzner, H., Rau, H. and Senger, H. (1965). Studies on the synchronizability of individual pigment-deficient mutants of Chlorella studies on synchronization of some pigment-deficient Chlorella mutants. Planta, 65(2): 186-194. 
Muller, U. (1996). Production rates of epiphytic algae in eutrophic lake. Hydrobiologia, 330: 37-45.

Pielou, E. C. (1975). Ecological Diversity. John Wiley and Sons, New York.

Pouličkowá , A., Duchosłav, M. and Doculil, M. (2004). Littoral diatom assemblages as bioindicators of lake trophic status: A case study from perialpine lakes in Austria. European Journal of Phycology, 39: 143-52.

Radwan, M., Willems, P. and Berlamont, J. (2004). Sensitivity and uncertainty analysis for river water quality modeling. Journal of Hydroinformatics, 6(2): 83-99.

Rejagopal, T. T., Thangamani, A. and Archunan, G. (2010). Comparison of physicochemical paramerers and phytoplankton species diviresty of two perennial ponds in Sattur area, tamilnadu. Journal of Environmental Biology, 31(5): 787-794.

Sabae, S. Z. and Abdel-Satar, A. M. (2001). Chemical and Bacteriological studies on El-Salam Canal, Egypt. J. Egyptian Academic Society Environmental studies Development, 2(1): 173-197.

Saha, S. B., Bhattacharya, S. B., and Choudhury, A. (2000). Diversity of phytoplankton of sewage pollution brackish water tidal ecosystems. Journal of Environmental Biology, 21 (1): 9-14.

Salman, J. M., Hadi, S. H. and Mutaer, A. A. (2013). Spatial and temporal distribution of phytoplankton and some related physical and chemical properties in Al-Abasia River (euphrates), Iraq. International Journal of Geology, Earth and Environmental Sciences, 3(3): 155-169.

Schwarzenbach, G. and Biedermann, W. (1948). Komplexone X. Erdalkalikomplexe von o,o'-Dioxyazofarbstoffen. Helvetica Chimica Acta, 31(3): 678-687.

Shannon, C. E. and Wiener, W. (1949). The mathematical theory of communication. Urbana, University of Illinois Press, $177 \mathbf{p p .}$

Sheen, R. T., Kahler, H. L., Ross, E. M., Betz, W. H. and Betz, L. D. (1935). Turbidimetric determination of sulfate in water. Industrial and Engineering Chemistry Analytical Edition, 7(4): 262-265. 
Shehata, S. A., Sabah, A. and Aly, G. H. (1996). Algal communities and its relationship with the water quality of River Nile at Edfu, Egypt. Scientific Journal of Faculty of Science, Monoufia University, 10: 265-286.

Shehata, S. A., Ali, G. H. and Wahba, S. Z. (2008). Distribution pattern of Nile water algae with reference to its treatability in drinking water. Journal of Applied Science and research, 4(6): 722-730.

Simpson, E. H. (1949). Measurement of diversity. Nature, 163-688.

Smith, M. E. and Manoylov, K. M. (2013). Changes in Diatom Biodiversity in Lake Sinclair, Bald win County, Georgia, USA. Journal of Water Resource and Protection, 5: 732-742.

Song, Y. Z., Wang, J. Q. and Gao, Y. X. (2017). Effects of epiphytic algae on biomass and physiology of Myriophyllumspicatum L. with the increase of nitrogen and phosphorus availability in the water body. Environmental Science and Pollution Research, 24(10): 9548-9555.

Stevenson, J. and Pan, Y. (1999). Assessing ecological conditions in rivers and streams with diatoms, Applications to the environmental and earth science, Cambridge, UK. Cambridge University Press, 30: 11-40.

Sundbäck, K. and Snoeijs, P. (1991). Effects of nutrient enrichment on microalgal community composition in a coastal shallow water sediment system: an experimental study. Botanica Marina, 34: 341-358.

Takashi, A., Munira, S., Jagath, M. and Takeshi, F. (2004). The effect of epiphytic algae on the growth and production of Potamoget onperfoliatus $L$. in two light conditions. Environmental and Experimental Botany, 52(3): 225-38.

Tamot, S. and Sharma, P. (2006). Physico-chemical Status of Upper Lake (Bhopal, India) Water Quality with Special Reference to Phosphate and Nitrate Concentration and Their Impact on Lake Ecosystem. Asian Journal of Experimental Sciences, 20(1): 151-158.

Toma, J. J. (2011). Physical and chemical properties and algal composition of Derbendikhan lake, Sulaimania, Iraq. Current World Environment, 6(1): 17-27. 
Toporowska, M., Pawlik-Skowrońska, B. and Wojtal, A. (2008). Epiphytic algae on StratiotesaloidesL., Potamogetonlucens L., Ceratophyllumdemersum L. and Chara spp. in a macrophyte-dominated lake. Oceanological and Hydrobiological Studies, 37(2): 51-63.

Tóth, V. R. (2013). The effect of periphyton on the light environment and production of Potamogetonperfoliatus, in the mesotrophic basin of Lake Balaton. Aquatic sciences, 75: 523-534.

Varadharajan, D. and Soundarapandian, P. (2014). Effect of physic-chemical parameters on species biodiversity with special reference to the phytoplankton from Muthupettai, South East Coast of india. Journal of Earth Science and Climatic Change, 5(5): 1-10.

Wilhm, J. L. and Dorris, T. C. (1968). Biological Parameters for Water Quality Criteria. BioScience, 18(6): 477-481.

Williams, V. and Twine S. (1960). Flame photometric method for sodium, potassium and calcium. Modern Methods of Plant Analysis, 5: 3-5.

Winkler, L. W. (1888). Die Bestimmung des in Wassergelösten Sauerstoffen. Berichte der Deutschen Chemischen Gesellschaft, 21: 2843-2855. 


\section{التعاقب الموسمي للكتلة الحيوية والطحالب الاقيقة في بعض المصارف الزراعية

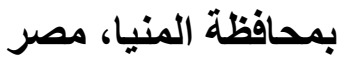

$$
\begin{aligned}
& \text { شيرين عبد الرؤف عبد السلام'، مصطفى فوزي ‘، وفاء حافظ “ وعادل أحمد فتحي؛ } \\
& 1 \text { - قسم علوم البيئة- معطر بحوث الأراضى والمباه والبيئة - مركز البحوث الزراعبة - مصر. }
\end{aligned}
$$

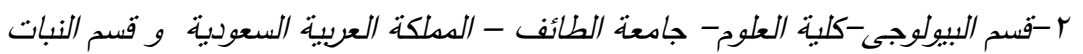

$$
\begin{aligned}
& \text { والميكروبيولوجى-كلية العلوم- جامعة أسيوط. } \\
& \text { r- قسم علوم البيئة- معهد بحوث الأراضى والمباه والبيئة - مركز البحوث الزراعية - مصر. } \\
& \text { ـ - قسم النبات والميكروبيولوجى -كلية العلوم- جامعة الدنيا. }
\end{aligned}
$$

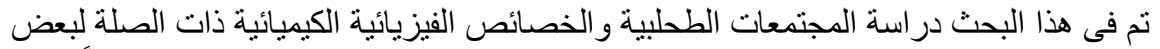

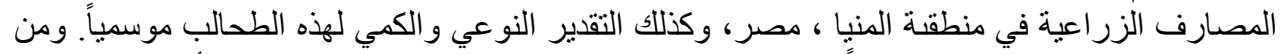

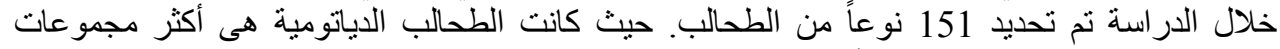

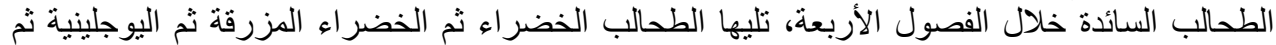

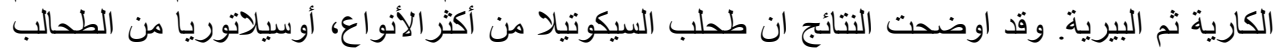

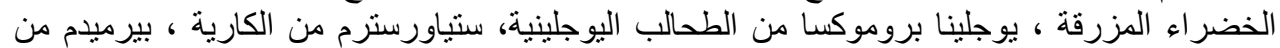

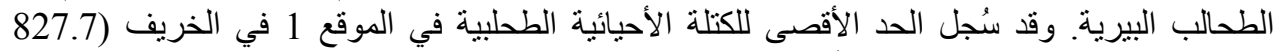

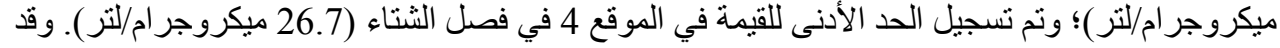

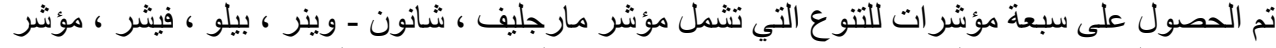

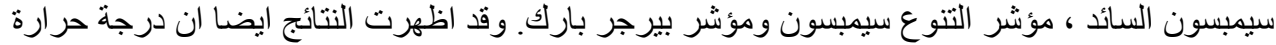

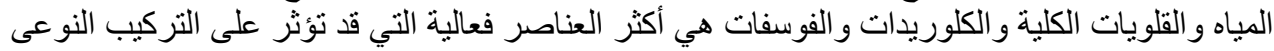
للطحالب الدقيقة خلال المو اسم المختلفة المبلة 